AperTO - Archivio Istituzionale Open Access dell'Università di Torino

\title{
Perspectives on front matter in monolingual dictionaries of Spanish and Italian
}

\section{This is the author's manuscript}

Original Citation:

Availability:

This version is available http://hdl.handle.net/2318/1774884

since 2021-02-28T21:24:19Z

Published version:

DOI:10.1007.s40607-020-00068-9

Terms of use:

Open Access

Anyone can freely access the full text of works made available as "Open Access". Works made available under a Creative Commons license can be used according to the terms and conditions of said license. Use of all other works requires consent of the right holder (author or publisher) if not exempted from copyright protection by the applicable law. 


\section{Lexicography}

\section{Perspectives on Front Matter in Monolingual Dictionaries of Spanish and Italian --Manuscript Draft--}

Manuscript Number:

Full Title:

Article Type:

Funding Information:

\begin{abstract}
:
Corresponding Author:

Corresponding Author Secondary Information:

Corresponding Author's Institution:

Corresponding Author's Secondary Institution:
\end{abstract}

First Author:

First Author Secondary Information:

Order of Authors:

Janet DeCesaris, Ph.D.

Carla Marello, Ph.D.

ALEX-D-19-00012R2

Original Article

(FFI2015-70375P)

Janet DeCesaris, Ph.D.

Janet DeCesaris, Ph.D.
Perspectives on Front Matter in Monolingual Dictionaries of Spanish and Italian

Ministerio de Economía, Industria y

Competitividad, Gobierno de España

Dr. Janet DeCesaris

This paper presents two short studies of front matter--one diachronic and the other synchronic--in the monolingual dictionaries of Spanish and Italian. Our study of the front matter in the various editions of the Spanish Royal Academy dictionary, which has undergone 23 editions over the past 240 years, takes a diachronic perspective and shows how front matter has developed, changed and expanded over time. Our study of the front matter in Italian is synchronic and concentrates on a representative case from one of the language's most consulted online language resources. We show that the front matter in current print dictionaries of both languages, much of which is aimed at helping users fully understand entries, is often missing from online resources. Taken together, these two studies allow us to reflect on the changing role of front matter in dictionaries and its importance for online dictionaries.

Universitat Pompeu Fabra

Barcelona, Cataluña SPAIN

Universitat Pompeu Fabra

Order of Authors Secondary Information:

Author Comments: 
Janet DeCesaris and Carla Marello

\title{
Perspectives on Front Matter in Monolingual Dictionaries of Spanish and Italian*
}

\author{
Affiliations: \\ Janet DeCesaris \\ Universitat Pompeu Fabra, Barcelona, Spain \\ Carla Marello \\ Università degli Studi di Torino, Torino, Italy \\ Corresponding author: janet.decesaris@upf.edu
}

\begin{abstract}
This paper presents two short studies of front matter-one diachronic and the other synchronic - in the monolingual dictionaries of Spanish and Italian. Our study of the front matter in the various editions of the Spanish Royal Academy dictionary, which has undergone 23 editions over the past 240 years, takes a diachronic perspective and shows how front matter has developed, changed and expanded over time. Our study of the front matter in Italian is synchronic and concentrates on a representative case from one of the language's most consulted online language resources. We show that the front matter in current print dictionaries of both languages, much of which is aimed at helping users fully understand entries, is often missing from online resources. Taken together, these two studies allow us to reflect on the changing role of front matter in dictionaries and its importance for online dictionaries.
\end{abstract}

Keywords: Dictionary front matter, Spanish Royal Academy dictionaries, Italian online dictionaries

\footnotetext{
* The authors are listed alphabetically. DeCesaris hereby acknowledges support from Grant FFI201570375-P (MINECO/FEDER) "Context-dependent Meaning and Polysemy, and its Implications for Lexicographic Representation" (PI, DeCesaris) awarded by the Ministry of Economy and Competitiveness of Spain. Carla Marello hereby acknowledges support from Dipartimento di Lingue e letterature straniere e culture moderne, Università degli Studi di Torino, Italy. A preliminary version of this paper was presented at the $22^{\text {nd }}$ Biennial Meeting of the Dictionary Society of North America held at Indiana University in Bloomington, Indiana.
} 


\section{Introduction.}

Front matter of dictionaries is often overlooked in dictionary research; a simple search for "front matter" in the proceedings of EURALEX congresses (https://euralex.org/publications/), for example, yields only 2 academic papers in the past three congresses $(2014,2016,2018)$. Yet the analysis of front matter lends itself to many different perspectives, because front matter has long formed part of published dictionaries. Front matter - the introductory material that appears in a printed dictionary before the entries under the first letter - has long been an integral component of printed dictionaries and typically includes a guide to the use of the dictionary. In the past the front matter of dictionaries has included essays on the history of the language, pronunciation, current usage, etymology, and grammar, although currently these essays, if they are included at all, are shorter than they were in the past (Landau 2001: 148-9). Landau further states that front matter has become shorter because "it is widely believed among lexicographers that no one reads it" (ibid. 148).

In our view, the insights and brief discussions offered by dictionary authors in prefaces and guides to using the dictionary point up both the continuity of and changes in dictionaries over centuries. As its name suggests, front matter occupied a specific — and salient—place in print dictionaries. The same is not necessarily true of online dictionaries, and thus a look at the characteristics and development of front matter is warranted in order to determine its role, if any, in a context of digital dictionary consultation.

The study of front matter of Italian and Spanish dictionaries is particularly interesting because both languages have long lexicographic traditions as well as many current online language resources. Although the creation of the Academia Real Española ('Spanish Royal Academy') in the $18^{\text {th }}$ century and its dedication to writing dictionaries of Spanish were certainly inspired by the Italian Accademia della Crusca (literally, 'Academy of the Bran'), the current state of lexicographic matters is quite different for these two languages. In Spain, the Academy dictionary, which is currently in its $23^{\text {rd }}$ edition, dominates the dictionary scene and the Academy, through its dictionary and other works, continues to set what constitutes standard Spanish around the world. The dictionaries of the Accademia della Crusca, on the other hand, have not enjoyed such continuity throughout its history and as a result, the monolingual Italian dictionary scene is quite varied and not dominated by a single publisher.

In this paper, we provide two short studies of front matter in the monolingual dictionaries of these two Romance languages. Given that the Spanish Royal Academy dictionary has undergone many editions over the past 240 years, the front matter in the Academy dictionary lends itself to a diachronic perspective to show developments and changes over time. To take a synchronic look at front matter for people consulting dictionaries today, we present a representative case from one of the most consulted online language resources for Italian. After we present these two studies, we conclude by reflecting on the changing role of front matter in dictionaries and its importance for online dictionaries.

2. Front matter from a diachronic perspective: A brief overview of front matter in the Spanish Royal Academy Dictionaries 1780-2014.

2.a. Dictionaries studied. The twenty-three editions of the dictionary of the Spanish Royal Academy (Real Academia Española, abbreviated as RAE) offer valuable insight into the development—and expansion—of front matter over time. The Spanish Royal 
Academy as a public institution has published dictionaries, grammars, orthographies and many other works since its founding in $1713 .{ }^{1}$ Since it is funded in large part by the Spanish government and thus indirectly by Spanish taxpayers, much of its work has been made freely available to the public, and the Academy's web page is particularly rich in information. On the RAE's website one can consult scanned pages of the editions of the Academy dictionaries in the Nuevo tesoro lexicográfico 'New lexicographic treasury/repository' (https://www.rae.es/recursos/diccionarios/diccionarios-anteriores-1726-1992/nuevotesoro-lexicografico) by looking up a specific word, and then clicking on the specific edition that one wants to consult. There is also an option, the Mapa de diccionarios ('Dictionaries map' https://www.rae.es/recursos/diccionarios/diccionarios-anteriores1726-1992/mapa-de-diccionarios), that allows viewers to simultaneously compare entries (though not front matter) from six particularly significant editions of the Academy dictionary, those from 1780, 1817, 1884, 1925, 1992, and 2001, thus providing an excellent picture of the historical development of the meaning of a word. This brief overview refers to those six editions, as well as to the current (2014) print edition (the online edition of which is continually being updated).

2.b. Access to front matter on the Spanish Royal Academy website. The Academy website does not handle a direct query of the sort "1884 edition front matter" for the editions before 2001; rather, one must first search for a word (any lemmatized word) in the Nuevo tesoro lexicográfico in each individual scanned edition (thus obtaining access to that edition), and then must click on the tab Prólogo 'Prologue'. Figure 1 points to this tab, which is located at the top of the screenshot.

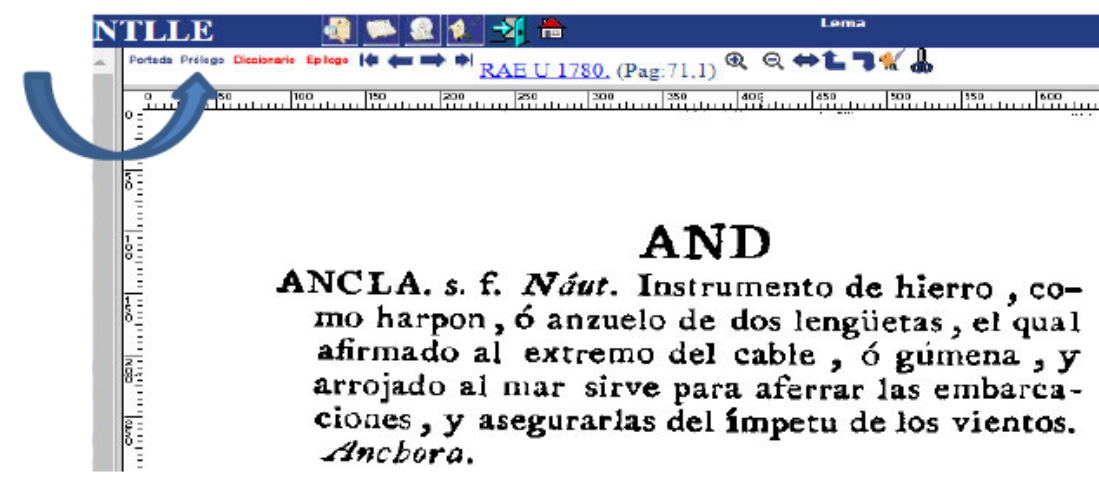

Fig. 1. The word Prólogo, indicated by the arrow (added by the authors), which provides access to the front matter of the 1780 edition; the word looked up is ancla 'anchor' (Nuevo tesoro lexicográfico http://ntlle.rae.es)

The front matter to the digitized editions of 2001 and 2014 editions is available online and can be accessed from the respective pages that introduce each dictionary (http://lema.rae.es/drae2001; https://www.rae.es/diccionario-de-la-lengua-espanola/la23a-edicion-2014), although one does not need to land on these pages in order to look up a word or phrase.

\footnotetext{
${ }^{1}$ For more information on the Academy and its dictionaries, see Zamora Vicente (1999).
} 
2.c. Features of front matter, 1780-2014. The first edition of what is often referred to in Spanish as DRAE (Diccionario de la Real Academia Española) was published in 1780 as a single volume dictionary. Because the dictionary is based on the Academy's own Diccionario de Autoridades, which appeared between 1726 and 1739, much of the front matter discusses the differences between this new, single volume and the earlier 6volume dictionary. The preface covers two pages and stresses the public's need for a dictionary that is both practical to consult and available at a reasonable price, thereby accounting for the Academy's decision to produce a single-volume dictionary that both deleted the citations and etymologies found in the Diccionario de Autoridades and introduced the extensive use of abbreviations to save space. In addition to the preface, the front matter also includes a list of the Academy members, the explanation of the abbreviations used, and a short list of errata.

The preface to the fifth edition of the Academy dictionary (1817), in addition to mentioning the need to have a dictionary available after the Napoleonic wars and some observations on orthography, makes two important contributions. The first demonstrates an interest in reducing and simplifying the usage labels in the dictionary. Two main changes were made: raro 'rare' and poco usado 'little used' are eliminated and the information they conveyed is subsumed under anticuado 'obsolete', and the labels bajo 'low', vulgar 'ordinary', festivo 'humorous, in jest', and jocoso 'merry, in jest' were all subsumed under familiar 'colloquial' because the differences among these four labels were too vague to permit their precise use. ${ }^{2}$ The second contribution of this preface concerns where multi-word expressions (including proverbs) are to be found. In previous editions, the Academy had said that multi-word expressions were listed under the most important word, but here notes that such a policy is at best ambiguous, at worst may lead to differing interpretations, and was not actually used consistently throughout the dictionary. As a result, it sets forth a policy based on the first word in the expression belonging to a specific lexical category, with the lexical categories being ordered nouns first, then verbs, then adjectives (and if an expression has none of these categories, it is listed under the first word). That system is by and large still used today. In addition to this 3-page preface, the front matter contains a list of Academy members who died between the publication of the $4^{\text {th }}$ and $5^{\text {th }}$ editions, a list of current members, and a list of abbreviations.

The front matter of the $12^{\text {th }}$ edition of 1884 is noteworthy for several reasons. For the first time the preface makes mention of Spanish in the Americas and the input from the academies that had been founded in Colombia, Mexico, and Venezuela following those countries' independence from Spain. The preface also notes that the Academy dictionary has included technical vocabulary and many neologisms while removing diminutives, augmentatives, and superlatives (which in Spanish are formed by means of derivational morphology). In addition to the preface, the front matter includes a list of members (which now contains much more information about their noble lineage and membership in other academies and is thus substantially longer) and a list of corresponding members, including those from the three Spanish American academies, two pages of abbreviations, and a single page of Reglas para el uso de este diccionario. These 'rules for using this dictionary' mark the first time any sort of explicit guide to using the dictionary is included in the front matter and cover important information for

\footnotetext{
${ }^{2}$ For a full discussion of the use of labels in Spanish dictionaries, see Garriga (1997). We note that in this edition the Academy defines the word "jocoso" as "alegre, festivo, chancero" (roughly, "merry', 'humorous', 'fond of a joke') ; given that "jocoso" and "festivo" are defined as synonyms, any difference between the two labels must have proved to be impossible to apply systematically.
} 
the user such as where to find multi-word expressions, where to find words that are used in more than one morphosyntactic category, and how senses are ordered.

The 15th edition (1925) of the Academy dictionary is best known for being the first with the title Diccionario de la lengua española ('Dictionary of the Spanish Language'), as opposed to Diccionario de la lengua castellana ('Dictionary of the Castilian Language'), and the preface discusses this change as recognition for the incorporation of many words from Spanish America and Spanish-speaking regions in Spain other than Castile. The preface also discusses a change in attitude on the part of the Academy, from what might be characterized as being highly protective of Spanish as written by classic authors such as Cervantes, Calderón de la Barca and Góngora, to a stance that was more open to the educated use of the time. The preface also states that each and every definition had been reviewed, and many revised, to ensure clear, concise definitions for modern readers. The guide to using the dictionary continues to be a single page and changes little from that of 1884 , providing the reader with instructions about where to find certain types of information in the entry.

The front matter of the $21^{\text {st }}$ edition (1992) of the Academy dictionary displays some changes from that of previous editions. Overall, the front matter (including the title page) occupies 31 pages. The preface is slightly shorter than in earlier editions, there is much less information about each member of the RAE, and most pages are filled by a complete listing of all the members of the corresponding and associated academies of Spanish from America and the Philippines. The guide to using the dictionary is 3 pages long and is structured with headings. In addition to expanding on the topics covered by earlier editions, the guide explains the transcriptions from nonLatin alphabets (notably, Greek and Arabic) and several Amerindian languages (Nahuatl, Quechua, Guaraní, Araucanian) that are used in etymologies.

The front matter of the two editions of the Academy dictionary from the $21^{\text {st }}$ century has changed dramatically; this is especially true for the current (2014) edition. As noted in section 2.b above, these two editions are digitized and the front matter is available online. ${ }^{3}$ The guide to using the dictionary is much more detailed than before: it includes directions for the use of the dictionary, a description of the types of entries and the information contained therein, comments on labels, examples, the role of derivational affixes and combining forms, in addition to several other sections. The list of abbreviations also includes the list of symbols used. In the $23^{\text {rd }}$ edition (2014) (which is now abbreviated DLE, for Diccionario de la lengua española, as opposed to the earlier DRAE), several sample entries are analyzed with specific explanations pointing out how to fully understand the conventions used.

\footnotetext{
${ }^{3}$ The list of all individual members of each member Academy of the Association of Spanish Language Academies ('Asociación de Academias de la Lengua Española') is not included as part of the online dictionary, but these names are available on the link to the Association (https://www.asale.org/) that may be accessed from the webpage introducing the 23rd edition (2014) (https://www.rae.es/diccionario-de-lalengua-espanola/la-23a-edicion-2014).
} 


\begin{tabular}{|c|c|c|}
\hline $\begin{array}{l}\text { Lema (palabra estudiada), } \\
\text { con moción de género. }\end{array}$ & \multirow{4}{*}{ 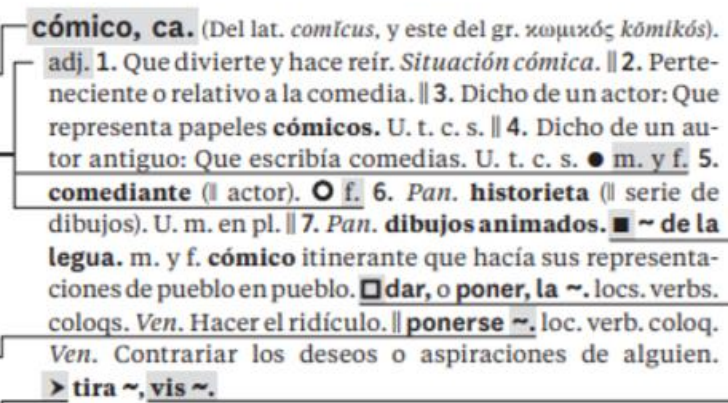 } & $\begin{array}{l}\text { Separación entre el bloque } \\
\text { de acepciones y el de formas } \\
\text { complejas (véase signos). }\end{array}$ \\
\hline Categoría gramatical. & & \multirow[b]{2}{*}{$\begin{array}{l}\text { Separación entre el bloque } \\
\text { de combinaciones estables } \\
\text { del lema y el resto de las } \\
\text { formas complejas } \\
\text { (véase sıGNos). }\end{array}$} \\
\hline Signo de palabra que & & \\
\hline $\begin{array}{r}\text { representa al lema } \\
\text { (véase sıGnos). }\end{array}$ & & \multirow{2}{*}{$\begin{array}{l}\text { Envio a un artículo que } \\
\text { recoge una combinación } \\
\text { estable del lema. }\end{array}$} \\
\hline $\begin{array}{l}\text { Inicio de los envíos a otros } \\
\text { lemas (véase signos). }\end{array}$ & \multirow[b]{2}{*}{$\begin{array}{l}\text { vis'. (Del lat. vis 'fuerza', 'potencia'). } \sim \text { cómica. f. Capacidad de } \\
\text { una persona, especialmente de un actor, para hacer reir. }\end{array}$} & \\
\hline & & $\begin{array}{l}\text { Forma compleja } \\
\text { (combinación estable) a la } \\
\text { que remite el envío anterior. }\end{array}$ \\
\hline
\end{tabular}

Fig. 2. Sample entry (that for cómico 'comic') analyzed in the front matter of the 2014 edition

More or less the same information for some sample entries can be found in prose in the 2001 edition, in section 4 Estructura de los artículos del diccionario ('Structure of dictionary entries'), section 5 Características de cada uno de los elementos de los que consta el artículo ('Characteristics of each element included in an entry'), and section 6 Contenido de las acepciones ('Content of senses') of the front matter, but the lack of a clear graphic presentation like that shown in Figure 2 limited the usefulness of the explanations. The 2014 preface addresses the role of the dictionary in society, the place of the standard language dictionary within the reference works produced by the Academy, and the meaning of "edition" in the digital age, among other topics. The preface does not address how the Academy proceeded to make decisions concerning words included in this edition (including the Academic commissions involved and the databases of Spanish consulted). That information is found in a section entitled $\mathrm{La}$ vigesimotercera edición ('The $23^{\text {rd }}$ edition'). The front matter now occupies 58 printed pages.

2d. Summary of findings. The diachronic look at front matter in Spanish Academy dictionaries reveals several changes over time. Figure 3 provides a brief comparison of the front matter in the seven editions of the Academy dictionary under consideration. 


\begin{tabular}{|c|c|c|c|c|c|c|c|}
\hline & 1780 & 1817 & 1884 & 1925 & 1992 & 2001 & 2014 \\
\hline \multicolumn{8}{|l|}{ Sections included in the front matter } \\
\hline Copyright page & & & & $\checkmark$ & $\checkmark$ & $\checkmark$ & $\checkmark$ \\
\hline Table of Contents & & & & & & $\checkmark$ & $\checkmark$ \\
\hline Preface ('Prólogo' or 'Preámbulo') & $\checkmark$ & $\checkmark$ & $\checkmark$ & $\checkmark$ & $\checkmark$ & $\checkmark$ & $\checkmark$ \\
\hline List of Academy members & $\checkmark$ & $\checkmark$ & $\checkmark$ & $\checkmark$ & $\checkmark$ & $\checkmark$ & $\checkmark$ \\
\hline $\begin{array}{l}\text { List of deceased Academy members (since } \\
\text { the } \\
\text { previous edition) }\end{array}$ & & $\checkmark$ & $\checkmark$ & $\checkmark$ & $\checkmark$ & $\checkmark$ & $\checkmark$ \\
\hline List of abbreviations used & $\checkmark$ & $\checkmark$ & $\checkmark$ & $\checkmark$ & $\checkmark$ & $\checkmark$ & $\checkmark$ \\
\hline Corrections & $\checkmark$ & & & & & & \\
\hline $\begin{array}{l}\text { People \& associations that aided the } \\
\text { Academy in preparing the dictionary } \\
\text { (includes Tabula Gratulatoria starting in } \\
\text { 1992) }\end{array}$ & & & $\checkmark$ & $\checkmark$ & $\checkmark$ & $\checkmark$ & $\checkmark$ \\
\hline $\begin{array}{l}\text { Information about lexicographic decisions } \\
\text { made in the edition }\end{array}$ & & & & & & $\checkmark$ & $\checkmark$ \\
\hline $\begin{array}{l}\text { Guide to the use of the dictionary: number of } \\
\text { printed pages }\end{array}$ & & & 1 & 1 & 3 & 20 & 7 \\
\hline $\begin{array}{l}\text { Number of pages in front matter, including } \\
\text { the title page }\end{array}$ & 7 & 7 & 15 & 18 & 31 & 57 & 58 \\
\hline
\end{tabular}

Fig. 3 Overview of the sections in the front matter of seven printed editions of the Spanish Academy dictionary

Perhaps the most striking change is the very substantial increase in front matter included in printed dictionaries, which is exactly the opposite of what Landau (2001: 148) observed in dictionaries of English. The sequence of the various sections in the front matter varies little; notably, the 'Guide to the use of the dictionary' preceded the list of abbreviations used in the 1992, 2001, and 2014 editions. Neither orthography nor pronunciation figure prominently in the prefaces to Spanish Academy dictionaries, although both are important topics in the overall mission of the Academy. These two topics are treated in separate reference works (Ortografía de la lengua española (2010) 'Orthography of the Spanish Language' for the most recent edition; Nueva gramática de la lengua española. Fonética y Fonología (2011) 'New grammar of the Spanish Language. Phonetics and Phonology'), thereby removing them from the sphere of dictionaries. A recurring theme in the prefaces is the justification of certain decisions made by lexicographers that might surprise the public, or that differentiate the new edition from the previous one. Emphasis has shifted from information about the authors and the challenges they faced while producing the dictionary, which was a dominant theme in the first one hundred years, to information aimed at helping users and showing how the dictionary can be used as efficiently and optimally as possible. In short, front matter has gone from being author-oriented to being user-oriented. This change in orientation is particularly evident in the digitized editions of the Academy dictionary, which display many sample entries with indications for use on the webpage introducing 
the dictionary while the names of Academy members can only be found through a series of links.

3. Front matter from a synchronic perspective: Electronic Versions of 20th-Century Italian Dictionaries

3.a. Dictionaries studied. Italian has a long lexicographic tradition that started in the 15 th century and continues today. There are several publishers who produce large-scale general monolingual dictionaries of the language; major dictionaries include Zanichelli, Garzanti, Devoto-Oli, Gabrielli, Sabatini-Coletti, De Mauro and the multi-volume Treccani, which is similar to an unabridged dictionary. All of these dictionaries are available in print as well as in digital format and some are available online. This study primarily refers to the Treccani dictionaries, which have been free online since 2009.

3.b. Access to front matter in works on the Treccani website. The Treccani website (http://www.treccani.it/) is a very important resource for Italians and for everyone interested in the Italian culture, history and language. It advertises itself as il Portale del sapere ('Knowledge Portal'), inviting us "Ricerca tra 1.015.347 lemmi e vocaboli" ('to look up among 1,015,347 entries and words'). This site has a series of very valuable reference tools that are free online, including an encyclopedia and a dictionary. The five printed volumes of the Treccani dictionary, by Aldo Duro, were first published in 1994 and comprise over 5,000 pages of text, with more than 900,000 definitions of words. The website includes Il Dizionario biografico degli italiani ('The Biographic Dictionary of Italians'), which began production in 1960 (and is still continuing today) and includes over 40,000 biographies. The portal also contains an atlas, a Dante Encyclopedia, an Encyclopedia of the Italian Language and Linguistics edited by Raffaele Simone, Gaetano Berruto and Paolo D'Achille (2010-11), and a Synonyms and Antonyms dictionary by Raffaele Simone (2003) that is considered among the best of its type.

Front matter to these works is not available on the Treccani website. Furthermore, given that many of the works on the portal have been updated over the years, it is important to know the edition being consulted, but that information is missing online, too. ${ }^{4}$ We may therefore ask if the information provided in front matter is essential to using the reference works and specifically the dictionaries on the portal, since Treccani itself has not provided access to it.

The lack of front matter is most surprising in the case of the Synonyms dictionary, which importantly uses a set of symbols (fortunately, a relatively small set: $\uparrow, \downarrow, \leftrightarrow$, and $\approx$ are the most commonly used) that are explained in the printed version but are not explained online.

The figure below (Fig. 4) reproduces a part of the third page of a detailed (ten printed pages) introductory guide to consultation. It is explained that $\approx$ marks the beginning of the article section devoted to synonyms; $\uparrow$ and $\downarrow$ indicate synonyms of a higher or lower register, respectively; $\|$ indicates analogous words which have some semantic relationship to the entry, $\Uparrow$ indicates hyperonyms and $\Downarrow$ hyponyms; and, ↔ marks the beginning of the antonyms section.

\footnotetext{
${ }^{4}$ A case in point: Marello needed this information for an article and the only way to obtain it was to write to the head editor, Dr. Luigi Romani, who kindly provided her with an answer. Later she discovered that some pieces of information indirectly given in https://it.wikipedia.org/wiki/Istituto dell\%27Enciclopedia Italiana.
} 

ti i sinonimi della voce a lemma, contrassegnati dai simboli seguenti:

$\approx$ questo simbolo indica l'inizio del campo dei "sinonimiv. Entro questo campo possono esserci (secondo la disponibilità del materiale) alcuni sottocampi, disposti nell'ordine seguente:

$\uparrow$ questo simbolo indica l'inizio del sottocampo dei "sinonimi marcativ. Esso contiene cioè parole e locuzioni che siano, rispetto a quelle riportate sotto il campo sinonimi, più forti, espressive, caratterizzate (tecnicamente, le parole (marcates);

$\downarrow$ questo simbolo indica l'inizio del sottocampo dei "sinonimi meno marcatis. Esso contiene parole e locuzioni che siano, rispetto a quelle riportate sotto il campo sinonimi, più deboli, meno espressive, meno caratterizzate (tecnicamente, le parole "non-marcaten);

II questo simbolo indica l'inizio del sottocampo degli "analoghiv: parole e locuzioni che, pur non essendo sinonimi del lemma, "hanno qualcosa a che fare" con esso. Esso raccoglie quindi quelli che nel gergo dei linguisti si chiamerebbero "co-iponimi", membri della stessa famiglia semantica o dello stesso campo semantico, ecc.;

$\Uparrow$ questo simbolo indica l'inizio del sottocampo degli (iperonimi): parole e locuzioni di uso più generale di quello del lemma. Questo campo è riempito solo quando possa riportare iperonimi significativi;

$\Downarrow \quad$ questo simbolo indica l'inizio del sottocampo degli (iponimiv: parole e locuzioni di uso più specifico di quello del lemma. Questo campo è riempito solo quando possa riportare iponimi significativi.

Fig.4. Avvertenze ('Guide') in the Treccani Synonyms dictionary (2003), printed version

A screenshot of the headword abolire 'abolish' as it appears online is presented in Figure 5. It is evident that the users of a synonym dictionary do not know which word to use instead of the one consulted or in cases of uncertainty: if they are given answers online without any explanation of the symbols, they are not helped in their search for a synonym. Each page of the printed version, in contrast, displays a legend of the symbols used at the bottom of the page (see Fig. 6). 
\begin{tabular}{lll}
\hline Sinonimi e Contrari & & \\
\hline Crea un ebook con questa voce | Scaricalo ora $(0)$ & Condividi $\boldsymbol{f}$ in
\end{tabular}

abolire v. tr. [dal lat. abolère] (io abolisco, tu abolisci, ecc.). - 1. [procedere ufficialmente all'abolizione di qualcosa: a. una tassa, una festività] $\approx$ annullare, cancellare, depennare, eliminare, revocare, rimuovere, sopprimere, [riferito a una legge, una norma, ecc.] (T) (giur.) abrogare, [spec. riferito a una sentenza e sim.] $\uparrow$ (giur.) cassare. $\leftrightarrow$ approvare, attivare, emanare, introdurre, [spec. riferito a una legge e sim.] varare. 2. (estens.) [decidere di tenersi lontano dall'uso di qualcosa: $a$. l'alcol] $\approx$ abbandonare, astenersi (da), desistere (da), eliminare, fare a meno (di), privarsi (di), rinunciare (a), smettere (con), (pop.) togliersi.

Fig. 5 Abolire 'abolish' in Treccani's Synonym and Antonym Dictionary online (2003)

abnorme /ab'norme/ agg. [dal lat. abnormis ufuori della regola)]. - 1. [di conformazione assolutamente fuori del normale: un essere a.] $\approx$ deforme, mostruoso. || obbrobrioso, orribile, orripilante, pauroso, raccapricciante, ripugnante, spaventoso. 2. (estens.) [che devia dalla norma: un fatto a.] $\approx \mathrm{e} \leftrightarrow[\rightarrow$ ABERRANTE].

abolire v. tr. [dal lat. abolēre] (io abolisco, tu aboli$s c i$, ecc.). - 1. [procedere ufficialmente all'abolizione di qualcosa: a. una tassa, una festività] $\approx$ annullare, cancellare, depennare, eliminare, revocare, rimuovere, sopprimere, [riferito a una legge, una norma, ecc.] (T) (giur.) abrogare, [spec. riferito a una sentenza e sim.] (T) (giur.) cassare. $\leftrightarrow$ approvare, attivare, emanare, introdurre, [spec. riferito a una legge e sim.] varare. 2. (estens.) [decidere di tenersi lontano dall'uso di qualcosa: $a$. l'al$\mathrm{col}]=$ abbandonare, astenersi (da), desistere (da), eliminare, fare a meno (di), privarsi (di), rinunciare (a), smettere (con), (pop.) togliersi. re male, fallire, (fam.) fare cilecca, (fam.) fare fiasco. $\leftrightarrow$ andare a segno, andare bene, andare in porto, avere buon esito, avere successo, riuscire.

aborto /a'borto/s. m. [dal lat. abortus -us, der. di aboriri "perire"]. -1 . [interruzione della gravidanza] $\approx$ interruzione di gravidanza. 2. (fig., spreg.) a. [persona o cosa mostruosa] $\approx$ mostro, mostruosità, obbrobrio, scherzo della natura. $\leftrightarrow$ bellezza, incanto, meraviglia, splendore. b. [lavoro mal riuscito, impresa non condotta in porto $e$ sim.: a. di un programma informatico, di una iniziati$v a] \approx$ fallimento, $(\mathrm{fam}$.) fiasco, flop, insuccesso, $($ fam.) patatrac, tonfo. $\leftrightarrow$ riuscita, successo.

abradere /a'bradere/ v. tr. [dal lat. abraděre «raschiar viay] (coniug. come radere), lett. - [togliere via mediante raschiamento] $\approx$ grattare, (non com.) radere, raschiare. $\Uparrow$ asportare, cancellare, rimuovere.

abrasione /abra'zjone/ s. f. [dal lat. tardo abrasio

$\approx$ sinonimi $\leftrightarrow$ contrari $>$ gradazioni $\uparrow$ più marcati $\downarrow$ meno marcati $\|$ analoghi $\star$... inversi

Fig. 6 Printed page from the Synonym and Antonym dictionary (Simone 2003) displaying the headword abolire 'abolish'

The lack of information is such that the usefulness of the dictionary is limited. As a result, Marello and Marchisio (2018) decided to provide an explanation for the symbols in the online version of the Synonyms dictionary in a portal aimed at teachers and learners called "Explore (with) digital dictionaries" (https://esploradizionari.ilearn.unito.it/). Among the exercises offered in this portal, there are some that are to be completed online with the help of the Synonyms dictionary. The people completing these exercises are told to read the instructions of the exercise carefully and their 
attention is drawn to the symbols in the feedback for specific answers, as shown in the feedback to Answer D in Fig. 7.

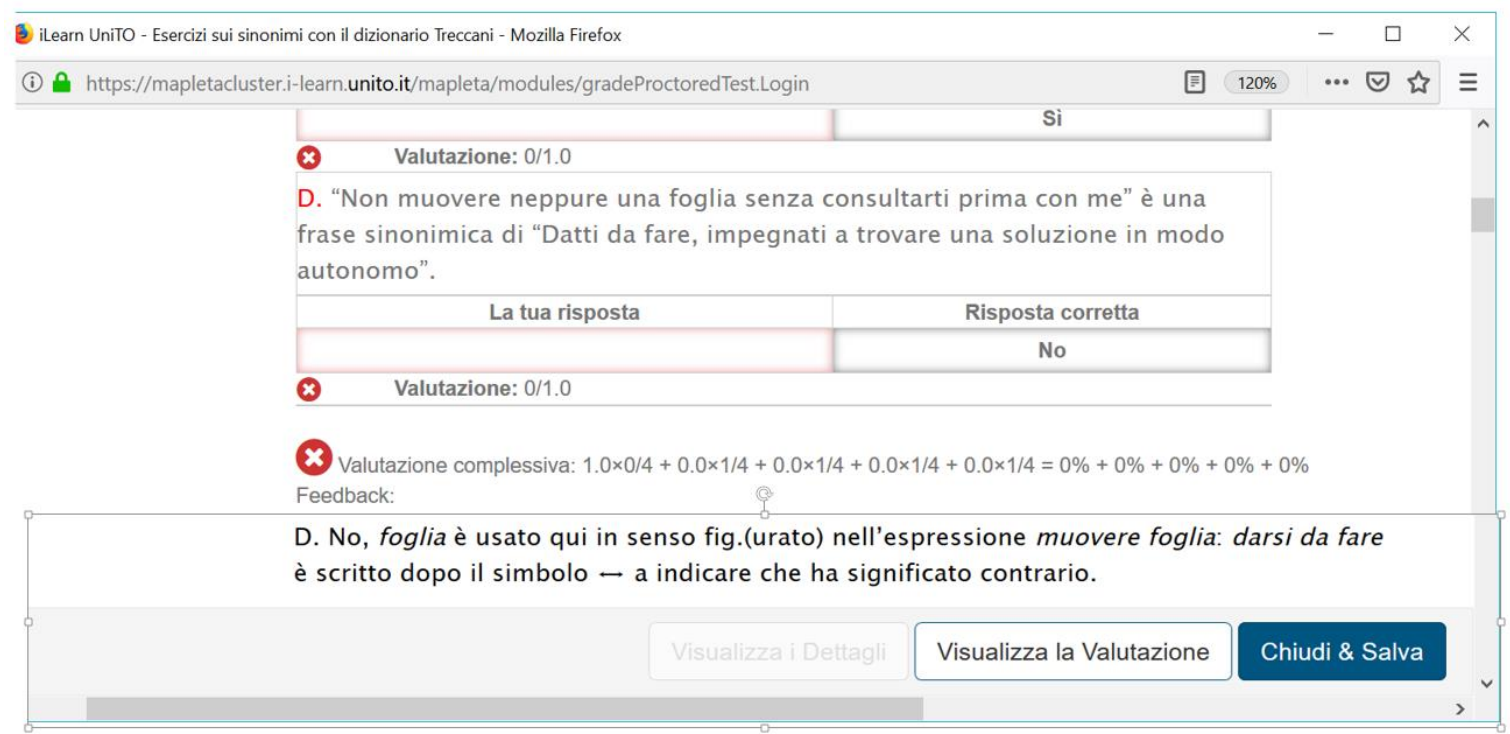

Fig. 7. Sample feedback ${ }^{5}$ on an exercise using the online Treccani Synonyms Dictionary, Feedback D. to be read by the testee to understand whether he/she made a mistake (MapleTA platform)

3.c. Front matter in other synchronic dictionaries of Italian. None of the general purpose Italian dictionaries freely available online contains front matter, with the exception of Nuovo De Mauro (https://dizionario.internazionale.it/). As a result, users are unaware of the dictionaries' size and coverage. The lack of front matter online also means that the dictionaries are unable to publicize their own strong points: the Garzanti Italian Dictionary online (http://www.garzantilinguistica.it/), for instance, offers a sort of "search full text" feature which you have to discover on your own.

Another case we can consider is that of Wörterbuch der italienischen Verben (WIV) by Peter Blumenthal and Giovanni Rovere (1998). The second edition appeared online (2017) with the instructions that are contained in the printed version-and these are very important in order to use it properly — but the instructions for the second edition of the digital version online were only partially effective, in spite of the very high quality of this dictionary (Marello 2018: 133). Front matter in the third digital edition (2019) has been substantially improved.

3.d. Summary of findings. Normal front matters of normal dictionaries without ideological content do not survive in the digital versions available on the internet. It appears as if only dictionaries behind paywalls, like that published by Zanichelli (http://dizionari.zanichelli.it/), as well as old historical dictionaries such as Vocabolario degli Accademici della Crusca, from the 17th century, and the Tommaseo Bellini dictionary, from the 19th century, maintain their extensive front matter online. The same also holds for Grande dizionario della lingua italiana (1961-2009), the great

\footnotetext{
${ }^{5}$ The feedback reads: 'Your answer is not correct the two sentences are not synonymous because foglia is used in the idiom muover foglia in a fig.(urative) meaning. The expression darsi da fare 'to get busy' is after the symbol $\leftrightarrow$ which indicates it has the opposite meaning.'
} 
historical dictionary of Italian which the Accademia della Crusca recently began to host on its site in a provisional online digital version: its 21 volumes, including the preface, index of quoted authors and 2009 supplement, are freely searchable. In essence, we only have online access to the front matter of the monumental dictionaries that have shaped the history of (meta)lexicography.

4. Discussion. Many of the concerns expressed in the prefaces to the early editions to the Spanish Academy dictionaries studied here (1780 and 1817) are still relevant to dictionary-making in 2020:

- practical constraints such as publication deadlines and insufficient funds;

- the need for concise definitions that are easily understood by the public;

- the need to include new words and senses;

- consistent application of usage labels;

- the role of dialectal forms in a large-scale general dictionary aimed at speakers in several geographic areas; and

- the placement of multi-word expressions in the dictionary.

Given the currency of these issues, it is surprising that front matter plays such a minor role in online dictionaries - to the point of disappearance - as shown in our study of Treccani. Most of the front matter from the print edition is still available to online users of the current issue of the Spanish Academy dictionary, which may be due to the fact that the Academy wants to underscore continuity in its lexicographic practice and wants speakers of Spanish to understand its rationale for certain decisions. In other words, the fact that a single dictionary has undergone 23 editions over 240 years and that it is the flagship product of a language academy, and not a commercial publisher, makes its treatment of front matter a special case.

Normal front matters of normal, general purpose dictionaries do not seem to survive in digital versions available on the internet. Some of the content, such as the lists of abbreviations and labels used, survive, but not in the form of lists in front matter: rather, we see them as expanded versions of abbreviations when the cursor passes over the abbreviation, as seen in the screenshot (Fig. 8) of the current online edition of Spanish Academy's Diccionario de la lengua española:

\section{finir Conjugar}

Del lat. finire.

1. intr. desus. Finalizar, acabar. U. en Col.

Usado en Colombia

Real Academia Española \& 1000 s los aerechos reservados

Fig. 8 "Usado en Colombia" 'Used in Colombia' expanded version when the cursor passes over "U. en Col."

Why is front matter not included in most online dictionaries? Are there any reasons for this disappearing act? One reason might be that publishers want to reserve front matter for the people who pay to use the dictionary. For example, the front matter in dictionaries published by Zanichelli is available because those dictionaries are behind a paywall. The relationship between front matter and payment might be a reason for the absence of front matter online. It may, however, also be that publishing houses consider front matter unnecessary for the very simple type of search that they allow in their free version, and they assume that professional users, for whom the front matter will be 
interesting, will be willing to buy paying versions. Although in many cases people are only interested in carrying out simple searches, it is also true that general purpose dictionaries offer a wealth of information that can be used in pedagogical settings in various ways, and in those cases more guidance is not only helpful but often necessary.

Publishers seem to underestimate the fact that young users might be unfamiliar with paper dictionaries and therefore not able to appreciate the difference between the digital version of a good paper dictionary and new lexical resources; as the role of print reference works declines and the role of computers in secondary education grows, users will increasingly have little experience with print dictionaries. It is, in fact, especially important for these users to be able to find online front matter that explains the coverage and structure of the dictionary that they no longer hold in their hands. New users who have never bought and looked up words on a CD-ROM or DVD version of a print dictionary ${ }^{6}$ do not notice that advance search options with Boolean operators are also disappearing from online dictionaries: if you are behind a paywall you can often recover them by downloading a searchable version and making the query offline, but users need to be expressly informed as to how to carry out this sort of search.

5. Conclusion. These two studies of front matter provide interesting perspectives on its relevance to dictionary consultation. Over more than 240 years and 23 editions, the amount of information in the front matter of the Spanish Royal Academy dictionary has increased substantially and is now user-oriented. Some of the indications aimed at helping users - specifically, those that provide the full form of abbreviations - are incorporated into the online visualization of the dictionary, but much of the information present in the user guide is not. In other words, online users cannot take advantage of the wealth of information made available in the printed editions. Similarly, we observed that dictionary front matter is not available on the Treccani website and this absence reduces its usefulness. In addition, some publishers have removed from their online dictionaries certain search capabilities that once were available in the electronic edition of print dictionaries. In the end, these "disappearing acts" are unfortunate, because all users - and especially teachers and students - would benefit from getting as much out of dictionaries as possible, both by reading the front matter and by exploiting their digital versions as the databases they indeed are.

6. Conflict of interest statement. On behalf of both authors, the corresponding author states that there is no conflict of interest.

\footnotetext{
${ }^{6}$ We note that currently Italian publishers like Zanichelli, Garzanti, and Devoto-Oli are increasingly turning to a downloading policy because many laptops no longer come equipped with a CD/DVD reader. The offer of dictionaries for Spanish on CD-ROMs and DVDs is limited and, like the offer for Italian, is shrinking: for example, the $22^{\text {nd }}$ edition of the Spanish Academy dictionary was available for purchase on CD-ROM but the $23^{\text {rd }}$ edition is not. The updated version of the $23^{\text {rd }}$ edition is available as an app requiring an Internet connection (free, with advertising) and the $23^{\text {rd }}$ edition, as originally published in 2014, may be purchased for downloading for offline use.
} 


\section{References}

\section{Dictionaries}

Accademia della Crusca. [Online resource] Accessed: http://www.accademiadellacrusca.it/ (15 July 2019).

Battaglia, Salvatore; Barberi Squarotti, Giorgio. 1961-2009. Grande dizionario della lingua italiana. [Online resource] Accessed: http://www.gdli.it/. (15 July 2019).

Blumenthal, Peter; Rovere, Giovanni. 1998. PONS Wörterbuch der italienischen Verben. Stuttgart: Klett. [Online resource] Wörterbuch der italienischen Verben Dizionario dei verbi italiani $2017^{2}, 2018^{3}$ Nürnberg: Acolada.

De Mauro, Tullio. 2001. [Online resource] Il Nuovo De Mauro. Accessed: https://dizionario.internazionale.it/. (15 July 2019).

Devoto, Giacomo; Oli, Gian Carlo; Serianni, Luca; Trifone, Maurizio. 2017. Nuovo Devoto-Oli. Il vocabolario dell'italiano contemporaneo, Firenze: Le Monnier.

Gabrielli, Aldo. Grande Dizionario Hoepli Italiano. [Online resource] Accessed: http://dizionari.repubblica.it/italiano.htlm (15 July 2019).

Garzanti Dizionario Italiano. [Online resource] Accessed: http://www.garzantilinguistica.it/. (15 July 2019).

Real Academia Española. 1726-1739. Diccionario de la lengua castellana (Diccionario de Autoridades). [Online resource] Accessed: http://web.frl.es (30 July 2019).

Real Academia Española. 2001. Diccionario de la lengua española. $22^{a}$ edición. [Online resource] Accessed: http://lema.rae.es/drae2001/ (30 July 2019).

Real Academia Española. 2014. Diccionario de la lengua española. La $23^{a}$ edición. Madrid: Espasa-Calpe.

Real Academia Española. 2018. Diccionario de la lengua española. [Online resource] Accessed: https://www.rae.es/diccionario-de-la-lengua-espanola/la-23a-edicion2014 (30 July 2019).

Real Academia Española. Mapa de diccionarios. [Online resource] Accessed: https://www.rae.es/recursos/diccionarios/diccionarios-anteriores-17261992/mapa-de-diccionarios (30 July 2019).

Real Academia Española. Nuevo tesoro lexicográfico. [Online resource] Accessed: https://www.rae.es/recursos/diccionarios/diccionarios-anteriores-17261992/nuevo-tesoro-lexicografico (30 July 2019).

Sabatini, Francesco; Coletti, Vittorio. 2018. Dizionario di italiano. [Online resource] Accessed: https://dizionari.corriere.it/dizionario_italiano/ (15 July 2019).

Simone, Raffaele. 2003. Dizionario dei sinonimi e dei contrary. [Online resource] Roma: Istituto della Enciclopedia Italiana. Accessed: http://www.treccani.it/sinonimi/ (15 July 2019).

Simone, Raffaele, Berruto, Gaetano; D’Achille, Paolo. 2010-11. Enciclopedia dell'italiano [Online resource] Roma: Istituto della Enciclopedia Italiana. Accessed: http://www.treccani.it (15 July 2019).

Tommaseo, Niccolò; Bellini, Bernardo. 1861-1879. Dizionario della lingua italiana Torino: Utet. Tommaseo Online. [Online resource] Accessed: http://www.tommaseobellini.it/\#/. (15 July 2019). 
Vocabolario della lingua italiana. 1994, 2008, 2017. [Online resource] Roma: Treccani. Accessed: http://www.treccani.it/vocabolario/vocabolario/ (15 July 2019).

MyZanichelli. [Online resource] Accessed: http://dizionari.zanichelli.it/ (15 July 2019).

Lo Zingarelli 2020 Vocabolario della lingua italiana. 2019. Cannella, Mario, Beata Lazzarini eds. Bologna: Zanichelli.

\section{Other literature}

European Association for Lexicography Publications. [Online resource] Accessed: https://euralex.org/publications/. (15 September 2019).

Garriga, Cecilio. 1997. Las «marcas de uso» en los diccionarios del español. Revista de Investigación Lingüística 1: 75-110.

Landau, Sidney I. 2001. Dictionaries: The Art and Craft of Lexicography. $2^{\text {nd }}$ ed. Cambridge: Cambridge University Press.

Marello, Carla. 2018. Recensione di Peter Blumenthal e Giovanni Rovere, Wörterbuch der italienischen Verben - Dizionario dei verbi italiani, digital edition, Nürnberg, Acolada, 2017. Lingua e Stile LIII: 129-140.

Marello, Carla; Marchisio, Marina. 2018. Dizionari digitali italiani in rete. Come farli conoscere a studenti della scuola secondaria. Quaderns d'Italià n. 23: 47-62. https://doi.org /10.5565/rev/qdi.237.

Real Academia Española. 2010. Ortografía de la lengua Española. Madrid: Espasa.

Real Academia Española. 2011. Nueva gramática de la lengua española. Fonética y Fonología. Madrid: Espasa.

Zamora Vicente, Alonso. 1999. Historia de la Real Academia Española. Madrid: Espasa Calpe. 